\title{
Rail Toward River: The Relationship Between Railroad and River Transportation in Korea During Japanese Rule
}

\author{
Hiroshi Dodoroki*
}

\begin{abstract}
The aim of this research is to analyze and periodize the relationship between railroad and river transportation as one aspect of the transformation of the land transportation system in Korea. As a result, three phases can be observed: a first phase of equality and interdependence (1910s); a second phase, subordinating rivers to feeder lines under railroad's dominance; and a third phase when trucks and buses became a major means for local transportation in place of traditional shipping routes. River ports were among the main planned destinations during the first and second phases, but such plans were changed or withdrawn after the third phase. This relationship between river and rail illustrates one geopolitical factor relating to the development of Korea's rail transportation network.
\end{abstract}

Keywords : Inland river transportation, Trunk railroad, Private railroad, River port, Korea under Japan's rule

\section{Introduction}

The modernization of Korea has been accomplished by imperialist countries against Korea's will. Similar modern transportation systems have been planned and constructed by Westerners throughout most Western colonies [1]. Geographers have developed various kinds of "colonial transportation development models" and applied these to many western colonies.

Nevertheless, as I have mentioned before [3], modern Korean transportation (Korea's trunk railroad, constructed for the Japanese to keep a direct route open to the Eurasian Continent) was developed under certain unique circumstances, differing from typical western models. In a previous thesis, I discussed its continuity, with traditional transportation chasing the geographical change of the transportation structure, especially the relationship between the railroad, which represented modern land transportation in Korea, and inland waterways, which influenced most freight transportation of the Jeseon era [2]. The research period for this thesis was set between 1899 when the first railroad was constructed and 1945 when Japanese rule in Korea ended.

\section{Pre-modern Land and Water Transport in Korea}

Although the size of the Korean peninsula is not extensive, there are many rivers that reach a length of over $500 \mathrm{~km}$ and have a wide drainage area. Due to the gradual slope and large

*Corresponding author.

Tel.: +81- 977-78-1111, E-mail: hstod@apu.ac.jp

(C)The Korean Society for Railway 2013

http://dx.doi.org/10.7782/JKSR.2013.16.4.348 flow rate of inland waterways, inland water transport became the major inland transportation mode, especially for cargo transport. Meanwhile, road transportation was mainly for passengers; roads were only for pedestrians or equestrians, not vehicles. For cargo, roads were effective only for short distances, used as branch lines connected to waterways.

Various goods were transported through the waterways. Downstream cargo consisted mainly of rafts of logs to be used for building or firewood in urban areas, and grain paid as tax, while major upstream freights provided items of daily necessity produced along the coastline, like salt, fish, and processed goods. Even if the cargo was official, such as tax grain, private shipping agencies took charge of its transportation. Public organizations owned tribute granary warehouses and supervised shipping companies. Each river basin had specific and exclusive shipping guilds that dominated both official and private cargo shipping, such as the Gyeonggang Guild in the Han River area. Marine transport was, of course, another possible option for shipping cargo. However, most preferred to use inland waterways, unless they had no choice, to avoid sea risks, including pirates and the muddy foreshore (gaetbol), the typical coastal environment along the Yellow Sea.

Therefore, along the trunk river, there used to be many river ports where regional commercial towns, so-called pogu, were located. Pogu had various economic and social functions, including marketplaces, taverns (jumak), commission agencies (gaekju), and tribute grain warehouses (jochang). Some pogu became regional centers (for example, Ganggyeong, Janghowon, Namji, and Yeongsanpo). Most major pogu were also ferry points for major roads, which meant a greater concentration of pedestrians and equestrians.

Some pogu remain major regional centers even today since they also became important nodes for modern land transport 
and water by their own centripetal force, but most of them declined to small villages after the waterway lost its power to the new land transport.

After the modern age, even though the waterway had lost its function as a trunk line, its local functionality often remained, until the 1960s when multi-purpose dams were constructed, simultaneously shutting their traditional traffic.

\section{Rail Construction and Waterline During the Modern Age}

\subsection{Development of Rail Transportation and its Relationship with River Transport}

Korea's modern age (from the western viewpoint) began in 1876 when the so-called Ganghwa Treaty was contracted between Korea and Japan, which forced the opening of major ports to imperialist nations. The imperialists (primarily Japan) tried to construct a modern transportation system in Korea, not only at its treaty ports (e.g., Incheon, Busan, Wonsan, Gunsan, and Mokpo), but also toward their hinterlands. Such a phenomenon (the emerging treaty port-hinterland line first) is often witnessed in other colonial railroad construction as well. In Korea's case, however, a trans-national trunk railroad from Busan (a southern port city connecting to Japan) to Seoul and Sin-euiju (along the northern border with China) was constructed by 1906 to support the Russo-Japanese War, while only one port-inland rail line opened between Incheon and Seoul. Trunk rail terminals therefore became important traffic nodes toward the hinterlands simultaneously with seaports, while in western models, such "inland trunk lines" did not emerge until almost the final phase of colonial transport development. This is a distinctive characteristic of Korea's modern transportation development process, which emerged for geopolitical reasons.

As treaty ports became hubs of land transportation around the coastal areas, major train stations became hubs for inner areas. In such areas, waterways gradually or rapidly lost their status as the Peninsula's trunk lines, and they then became part of the system of branch lines that made up the rail-centered inland transportation network, just as traditional road transportation had served the trunk waterways during the early modern age. On the other hand, in some of the river basins that were out of the railroad's influence, waterways still functioned as trunk lines. Thus, there were two types of transportation systems during the same age, depending on the region, and each had different periodical backgrounds.

In the period of transition from a water-centered system to a rail-centered system, there was a temporary phase of concurrence, in which each system tried to utilize the strength of the other before the complete decline of the waterways.
The transformation of the relationship between river and rail will be examined below, from the viewpoint of the planning and construction of the railroads' origins and destinations, in order to develop a periodization of this time.

\subsection{Phase 1: Rail Toward River Port}

During the early phase of Korea's railroad development, by 1914 , the trans-national rail frame had already been constructed, with an X-shaped network from Seoul to the four edges of the peninsula: Gyeongbu Line from Busan to Seoul; Gyeongeui Line from Seoul to Sin-euiju; Gyeongwon Line from Seoul Yongsan to Wonsan; and Honam Line from Daejeon to Gunsan and Mokpo. These immediately replaced the river's role as the regional trunk line wherever their routes competed with each other. Otherwise, especially during this early phase, the two systems acted supplementally in completing the regional trunk line network.

From the standpoint of rail construction, there was also a practical reason to connect river lanes. Since the early northsouth trunk line was rapidly constructed for geopolitical and military reasons, construction was carried out simultaneously at each separate work zone along the line, and some zones had no way to obtain materials except by river transport. Thus, when detailed routes for the line were planned, including route changes and the construction of short branch lines, connection with a river port was preferentially considered.

In the case of the Gyeongbu Line, direct connection points with the Geumgang River were constructed at Bugang and Sintanjin, both having long been important river ports. Short branch lines were also opened from Samnangjin to Nakdongang River Station and Waegwan Station to Waegwan River port, to connect the Nakdonggang waterline for the transshipping of rail materials. Kenjiho Line and Kenjiho River Port were constructed from Hwangju along the Gyengeui Line to Kenjiho Port (named for Kenji Watanabe, who conducted its construction) exclusively for carrying rail materials.

Later, these transshipment points for rail construction became major commercial points, both for the river line and the railroad, and thus regional centers, because of their privilege as transportation key points. Many of these then remained as regional centers even after the waterline declined.

After trunk line construction was completed, local conveyors sought a connection with river ports. In 1911, regional merchants constructed $1.1 \mathrm{~km}$ of tramway, using a man cage, to connect Waegwan Station with river ports. (It is not clear if the private tramline succeeded in ruining the former branch of the Gyeongbu line, built for rail construction, mentioned above). At Ganggyeong, one of the most famous pogu markets since the Joseon Era, merchants connected the Honam Line station to the port of Geumgang River by man-powered tram in 1921 . 
In 1914, the tram between Gimjae Station of the Honam Line and the Dongjin River started operation. During this phase, some found their own business opportunity in connecting rail and water. These efforts were aimed at connecting two different modes of trunk line with different hinterlands. In other words, during the first phase, even if the periodization is slightly different depending on the area, the relationship between trunk rail and trunk waterline was complementary and equivalent because the density of the rail network remained low.

\subsection{Phase 2: River as a Branch of Rail}

In the 1920s, the power of river transportation as trunk line gradually declined and was replaced by rail because of the extension of the trunk railroad. During this period, however, river transport was still important for local logistics. Thus, some private railroads included connections with river transport.

After the 1920s, the Japanese Government-General of Korea commenced political planning and the construction of private railroads, in order to direct Japanese capital investment to boost local rail construction. Meanwhile, the government concentrated on the extension of trunk lines.

In 1913, the government had posted initial proposed lines for private investors, including such lines as [4]:

1) Seonghwan (Gyeongbu Line) via Janghowon to Yeoju, 61 miles

2) Janghowon to Chungju, 37 miles

3) Bugang (Gyeongbu Line) to Cheongju, 15 miles

The main purpose for lines (1) and (2) was to link the trunk railroad with the port towns of the Hangang River, which brought the midstream and upstream waterline under the influence of the railroad system through local rail connections. Line (3) was the linkage between inland city and trunk line stations located at river port towns. Line (3) was opened in 1921 by the Chosen Central Railroad Company, but its junction with the Gyeongbu Line moved from Bugang to Jochiwon, implying the relative decline of the pogu town's status.

During the 1920s, many private rail companies also established planned lines along with the government lines and their own original lines.

- 1917: Chosen Central Railroad, Jochiwon to Chungju, 58.4 miles

- 1919: Chosen Forest Railroad, Hamhung via Jangjin to Huju and Manpojin, 217 miles

- 1919: Yanggang Colonization Railroad, Gomusan to Hapsu and Gilju to Hyesanjin, 205 miles

- 1919: Chosen Gyeongnam Railroad, Cheonan via Janghowon to Yeoju
- 1920: Northern Industrial Railroad, Hoeryeong to Geumdong

- 1920: Chosen Gyeongdong Railroad, Suwon to Yeoju

- 1927: Southern Chosen Railroad: Suncheon to Yongdangpo and Samyeongri

All of the above were either partially or entirely connected with upstream river transportation for the sake of dominating the hinterlands. Some companies competed to capture the entire trade of fruitful river basins, which led to the formation of freak-shaped rail lines, especially in the South (Nam)-Hangang River area, and this became one of the major characteristics of Korean colonial railroads. In the case of the Chosen Gyeongdong Railroad, they directly operated an inland shipping route from Yeoju Station to Heunghori, a traditional pogu town, to gain an advantage against their competitors.

In this phase, the relationship between rail and river can be compared to that between ruler and subject.

\subsection{Phase 3: Vehicles to Replace Ships}

In 1934 the Chosen Gyeongdong Railroad's connecting shipping service stopped operation, as expanding direct-operating truck connection service took over, covering almost all of the South Hangang River's drainage area, and regions beyond, such as Wonju, Jecheon, Danyang, Hoengseong, and Pyeongchang up to the Gangreung-fronted eastern shore. The extension of highways (the so called "Sinjakno", straight formed roads for vehicles constructed by the Seoul government or local government) and emerging competitive truck and bus services rapidly deprived water lines of connecting transportation service with rail, and sometimes even usurped the role of the local railroad.

Therefore, during the 1930s, the planning of most proposed private railroads no longer considered river ports as main destinations, while connection with seaports to link with Japan was still one of the main purposes. The South Chosen Railroad applied their plan to link the southern Honam region and Yeongsangang River in 1927, and began operation in 1935, changing their destinations to Honam Line and Gwangju City instead of river ports. Thus, railroads that had not yet completed construction by this time had to reset their destinations, adopting such a circumstantial change, or withdraw their plans entirely. After 1930, rail links with the river took place only for specific reasons, such as dam construction.

\section{Conclusion}

The geographical relationship between railroads and inland water lines in Korea can be divided into three phases, even though periodization is variable depending on the region. The 
first phase, around the 1910s, is marked by an equal, interdependent relationship between the early constructed trunk railroad and long distance river lanes. During the second phase, around the 1920s, there was a kind of role allocation between them, wherein the railroad was the regional trunk line and river shipping served as its feeder traffic. The third phase, around and after the 1930s, could be defined as the age of the river's decline as an important player in the inland transport system, when they were replaced instead by emerging road vehicle transportation. Nevertheless, we can still observe many traces of the water lane and its traditional importance in transportation in the routes of current railroad maps and the location of riverside towns connecting with rail stations.

\section{References}

[1] E.J. Taaffe, R.L. Morrill, P.R. Gould (1963) Transport expansion in underdeveloped countries: a comparative analysis, Geographical Review 53, pp. 503-529.

[2] H. Todoroki (2004) Transformation of Korean Road Transportation Pattern in former $20^{\text {th }}$ Century, PhD Thesis, Seoul National University.

[3] H. Todoroki (2005) After thought on the model of modern transportation system in Korea, Cultural and Historical Geography, 17(3), pp. 56-68.

[4] Senkokai (1986) Transport History in Korea.

접수일(2013년 8월 1일), 게재확정일(2013년 8월 9일)

Hiroshi Dodoroki : hstod@apu.ac.jp

Department of Asia Pacific Studies, Ritsumeikan Asia Pacific University, 1-1 Jumonjibaru, Beppu, Oita 874-8577, Japan 